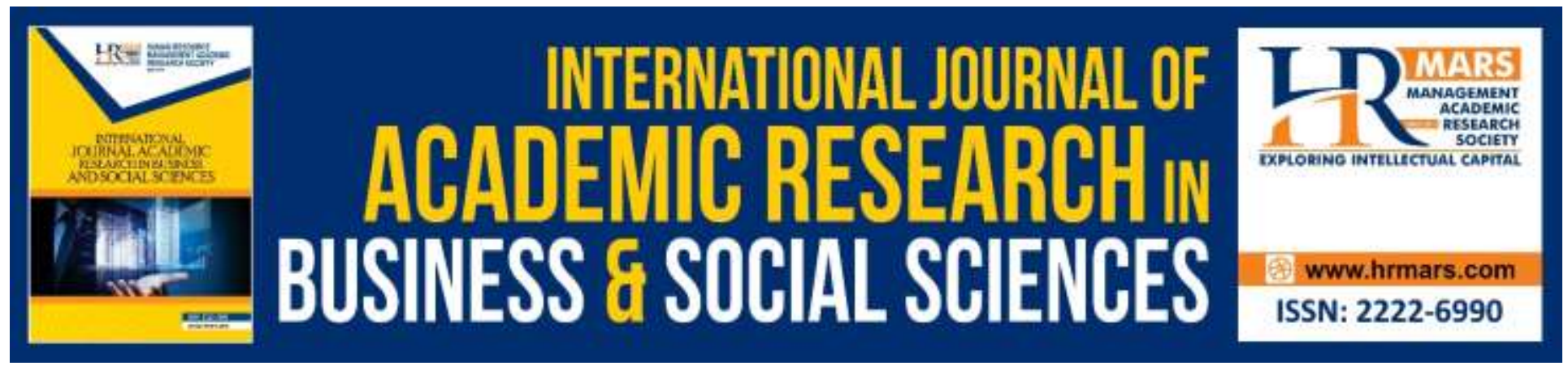

\title{
Sport Education in Primary School in Malaysia
}

\section{Mirza Azny Mustafa \& Norhana Md Salleh}

To Link this Article: http://dx.doi.org/10.6007/IJARBSS/v8-i12/5318

DOI: 10.6007/IJARBSS/v8-i12/5318

Received: 02 Nov 2018, Revised: 02 Dec 2018, Accepted: 27 Dec 2019

Published Online: 05 Jan 2019

In-Text Citation: (Mustafa \& Salleh, 2018)

To Cite this Article: Mustafa, M. A., \& Salleh, N. M. (2018). Sport Education in Primary School in Malaysia. International Journal of Academic Research in Business and Social Sciences, 8(12), 1723-1730.

Copyright: (C) 2018 The Author(s)

Published by Human Resource Management Academic Research Society (www.hrmars.com)

This article is published under the Creative Commons Attribution (CC BY 4.0) license. Anyone may reproduce, distribute, translate and create derivative works of this article (for both commercial and non-commercial purposes), subject to full attribution to the original publication and authors. The full terms of this license may be seen

at: http://creativecommons.org/licences/by/4.0/legalcode

Vol.8, No. 12, 2018, Pg. 1723 - 1730

http://hrmars.com/index.php/pages/detail/IJARBSS

JOURNAL HOMEPAGE

Full Terms \& Conditions of access and use can be found athttp://hrmars.com/index.php/pages/detail/publication-ethics 


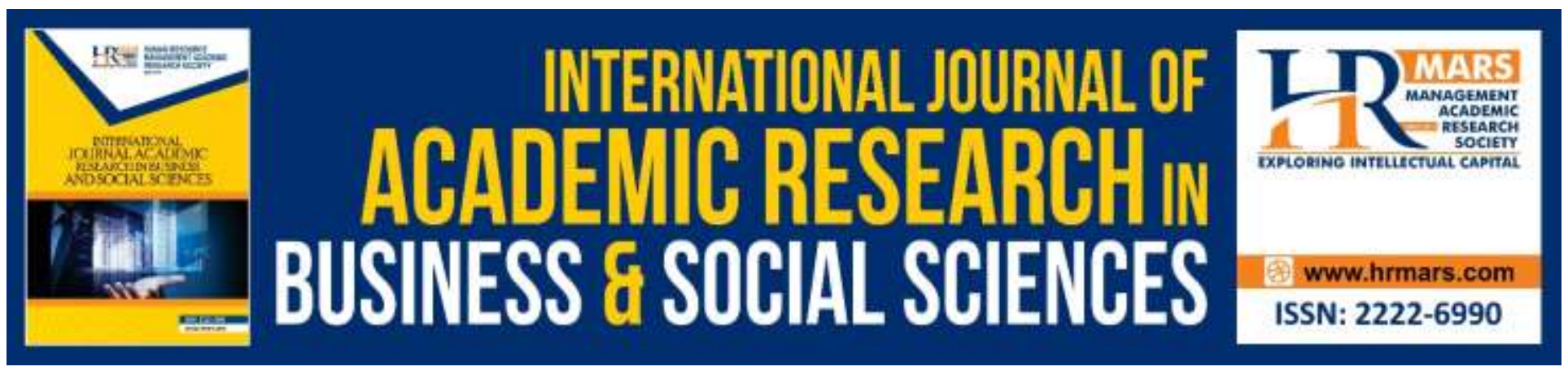

\title{
Sport Education in Primary School in Malaysia
}

\author{
Mirza Azny Mustafa ${ }^{1} \&$ Norhana Md Salleh² \\ ${ }^{1}$ Faculty of Sport Science and Coaching, Universiti Pendidikan Sultan Idris, 35900 Tanjong Malim, \\ Perak, Malaysia \\ ${ }^{2}$ Centre of Language and Social Studies, Universiti Pendidikan Sultan Idris, 35900 Tanjong Malim, \\ Perak, Malaysia
}

\begin{abstract}
Sports education or physical education policies begin at school. Sports education is a curriculum and teaching model designed to disseminate physical education programs at primary and secondary levels. The sports education's goal is to analyze and understand sports through pedagogical perspectives and effective methodologies. This concept paper was written to give several information on the relevancy of sports education in school.
\end{abstract}

Keywords: Sport Education, Primary School, Effective Methodologies

\section{Introduction}

The sport education policy aims to provide children and teens with a real and fun sports experience. Sports education always complements academic learning as it will give and show the personality of the students as a whole. A good athlete is an individual who is able to comply with rules and regulations in a game. Sports enhance quality such as leadership, discipline, partnership, teamwork, honesty, team spirit, tolerance and more among students. These days, we can see that most schools management realize that education is not only focused on academics but focuses on the holistic development of individuals from children and sports plays an important role in the development of the best personality to start a career early in life.

Efforts through the correct steps in the selection of professional sports coaches in primary and secondary schools should be implemented in the right way to ensure that trained athletes or individuals are able to master any changes and future challenges (Karim \& Nadzalan, 2017a; Karim, Ghafar, \& Nadzalan, 2018; Karim \& Nadzalan, 2017b). Special time should be given to sports education and parents should play important role by encouraging their children to participate in sport at an early age to ensure the aspirations and direction of athlete development are achieved. Sports education facilitates more internal motivation for students, but without the preparation of well-designed additional curriculum outputs, the potential transfer to physical activity will be difficult to be achieved (Siedentop, 1994). In the curriculum teaching structure, students will gradually take greater responsibility for learning while teachers will play a role in direct or indirect 
teaching. The roles of the teachers in this case are very important. Thus, it is important to ensure that the teachers have the ability to conduct and deliver the information to the students.

Sports education is a curriculum and instructional model that is planned in the search for ways to educate and deliver sports in the school curriculum and allow sport-based activities to have more meaning and value for various students (Siedentop, 1994). In order to achieve this 'authenticity of experience', Siedentop has combined six key features of the sport that need to be institutionalized into a model where the features are affiliates, seasons, formal competition, record, celebrations and peak events.

While the earliest research on sports education focuses on teacher and student feedback on models, this new focus is on how best to introduce and teach key pedagogy. It is implemented either through formal professional development (Siedentop, 1998), or through instructions or experience with pre-service teachers.

The Traditional Program (PETE) takes the basic approach when pre-service teachers use different sports education and curriculum where it includes a series of courses and basic, secondary and advanced content methods, pre-supervised field experience and subsequently to industrial training or field work methods. Model-based approaches are an alternative to a more traditional approach to organizational approaches as it involves self-taught courses and initial field experience for each curriculum model to ensure pre-service teachers learn how to deliver. The disadvantage of this approach is that it does not allow pre-service teachers to implement sports education (or other models) during PETE and pre-service teachers need more time to assimilate and understand the model and increase the probability they will succeed in delivering (Jenkins, 2004; McCaughtry, Sofo, Rovegno, \& Curtner-Smith, 2004; Stran \& Curtner-Smith, 2009a; Stran \& Curtner-Smith, 2009b).

Researches showed that university-based seminars and courses, or web-based workshops are generally inadequate for pre-service teachers (Sinelnikov, 2009; Stran \& Curtner-Smith, 2009b). The previous researchers also realized that pre-service teachers had the opportunity to see a model in action where it was able to provide a positive and significant experience for pre-service teachers. However, there is lack of systematic approaches or detailed study of a group through the four stages of the process of learning, acting, planning, and teaching.

\section{Challenges in Sports Education}

Sports education is a child-friendly concept in improving motor skills, fitness and health through physical activity (McKenzie \& Sallis, 1996). According to Bailey (2006) sports education in primary schools is an important element that needs to be implemented to achieve healthy lifestyle goals in children. Therefore, in achieving the goal of promoting healthy lifestyle, early education needs to be applied at the primary level (Wuest \& Bucher, 1991). Some of the previous researches focused on sports aspects, curriculum, training programs, professional development and teachers, evaluation in sports education and physical education perceptions (Strikwerda-Brown \& Taggart, 2001).

Sports education has positive impact when practiced by children. A study from Bailey (2006) on sports education at the school level create debate among the researchers. Although children are physically active in their developmental phases, it is questionable whether the Physical and Health Education (PJK) are practiced well and effectively by children in school. For example, manipulative skills such as threw the ball and kicked with the correct technique(Gabbard, LeBlanc, \& Lowy, 1994). 
Therefore, quality physical activity should be based on the core of sports education through effective co-curricular programs, learning methods and co-curricular strategies (Strikwerda-Brown \& Taggart, 2001; Rahmat et al., 2017; Rahmat, Shahril, Salimin, Ahmad, \& Nadzalan, 2017; Rahmat, Shahril, Salimin, Ahmad, \& Nadzalan, 2018). Jenny (1961) argue that sports education practiced through activities physically affect the physical, mental and social development of children.

The curriculum is the scope and content of a subject that includes learning both in and out of the classroom (Kulinna, 2008) while physical education is a science that aims to educate people to improve their achievement through physical activity to achieve a particular goal. Achievement of the goals is as stated by the Curriculum Development Center (2001) that are improving and maintaining health-based fitness and motor treatment, mastering basic skills of movement and games according to self-esteem, exercise and physical activity as a daily routine, apply health knowledge and safety while participating in various physical activities, shaping selfishness, and making wise choices in life.

The PJK Curriculum in Malaysia was formulated to meet the needs of individual growth and development to create a vibrant, prosperous and productive society. The curriculum is divided into three learning resources namely Fitness, Skills and Sports. These three pillars help achieve PJK goals and objectives. The PJK curriculum is determined by the Ministry of Education but the teacher also plays a role in determining the curriculum of the subjects. PJK is the only subject that can produce comprehensive education including psychomotor, cognitive, affective, social and emotional domain (Bucher \& Wuest, 1983).

The study of Colfer, Hamilton, Magill, \& Hamilton, (1986) on teaching methodology in physical education and health find that learning processes can bring success to a group of students. Education in the PJK class gives students the opportunity to try and experience the learning process through their involvement in physical activity. Therefore, these subjects require a more solid teaching approach in order to produce a comprehensive and effective education process. The main objectives of the PJK are based on three main domains namely psychomotor, cognitive and affective domains (Hattie, Marsh, Neill, \& Richards, 1997).

Therefore, physical education subject is an important component of the country's education curriculum to produce healthy and vibrant young people through emphasis on psychomotor, cognitive, affective and physical fitness. However, the emphasis on the implementation of physical education subjects is still lack of attention by the school and other parties. Therefore, a review of the curriculum is aimed at helping students make them healthy and fit through physical activity in everyday life.

\section{The Features of Effective Sports Education Training Program Education Training}

The study of McKenzie et al. (1996) on sports education at school by applying the Child and Adolescent Trial for Cardiovascular Health (CATCH) program at 96 schools and 4 states found that moderate-to-vigorous international guidelines for adolescent physical activity (MVPA) interventions increased by $37.4 \%$ to $51.9 \%$ over non-intervention groups. The program comprises the first three focus areas involving students, classrooms and physical education teachers. Classroom activity includes games designed for aerobic activity, jump rope and others through color selection. 
Through the findings, researchers conclude that teachers need to perform physical activities in the classroom while school'staffs also play role by monitoring the program. It was also suggested that schools are essential to promote a healthy lifestyle among students.

Therefore, for effective learning, the PJK must be based on the understanding of the general nature of the specific needs and characteristics of the student's behavior in which physical education uniquely contributes to student' growth and development (Knapp \& Hagman, 1953). Preparation and development of the curriculum should be seen based on what has been done to incorporate the interests, needs and backgrounds of students' education and their achievement, curriculum content should be in line with the level of student knowledge.

One of the roles of PJK teachers at school is to change and provide activities that suit their interests and abilities (Wuest \& Bucher, 1995). The main goal of the PJK is to socialize students in physical activities that fit their needs and interests. Darst, Pangrazi, Sariscsany, and Brusseau (2006) stated that the most important goal in the secondary school education program is to help young people to incorporate some forms of physical activity into their lifestyle.

\section{Professional and Teacher Development}

School administrators should pay serious attention to the subjects of physical education because these subjects are vital to the fitness of the body and thus generate mind intelligence. The success of a school depends largely on how the headmasters or administrators are able to practice authoritative leadership styles. The authoritative leadership covers a widespread knowledge of the aspects of school management.

These include office management, curriculum management, staff development, motivation for teachers, students and school staff, relationships with other sectors and improving school performance (Ministry of Education, 1998). Similarly, in managing the administration of physical education subjects, administrators cannot make double standards by focusing on the subjects of the examination (Hoe, Hua, \& Shaari, 2004).

Muda (2009) argues that school administrators often place teachers teaching the physical education subject as a complement to the number of teaching time. This is due to the shortage of teachers who really specialized in the subject. The situation is becoming more serious when the school administration thinks physical education subjects do not need teachers who are proficient about physical education.

\section{Assessment in Sports Education}

Teachers in developed countries are trying to diversify their teaching methods so that students can be given relevant information about healthy lifestyle(Pantanowitz, Lidor, Nemet, \& Eliakim, 2011; Sallis \& McKenzie, 1991). The implication, obesity in children is increasingly contagious in developed countries. Hardman and Marshall (2009) explain in Europe, the level of community awareness has increased in the 1990s with the establishment of the International Council for Sport Science and Physical Education (ICSSPE). The council has distributed questionnaire instruments to schools in member countries to know the development of a country's efforts in implementing the teaching of physical education subjects. 
The results obtained from a survey conducted by the United Kingdom Northwest Countries Physical Education Association (2014) in collaboration with UNESCO around the world in relation to the implementation of the Physical Education curriculum found that only $79 \%$ of countries adopt the standard physical education curriculum. In terms of the importance of the PJK subjects, $54 \%$ of the subjects placed physical education subjects as unimportant subjects with other academic subjects. In terms of implementation, only $71 \%$ of the countries are implementing this subject by following the actual curriculum. Hence the most important thing as a result of the survey shows that only $53 \%$ of teachers are eligible to teach the subject (Marshall \& Hardman, 2000).

\section{Perception of Physical Education}

PJK is a subject that is considered less important by the school, parents and some students. The subjects can be taught by teachers who are not specifically trained in the physical education and lack of a rigorous assessment system (Jani, 1994). Syed Ali (2011) in his study found that parents, teachers and school administrators often underestimate the importance of the physical education subject. Parents lack understanding on the importance of the physical education subject, the physical education teachers reluctantly teach the physical education subject as no examination and the administrator regarded the physical education subject as a balance and complementary timetable in which the teacher considered to be capable of teaching these subjects.

Wee (2013) found that only six to 30 percent of teachers are teaching the physical education subject properly and effectively. Other than that, they just teach by throwing the ball and letting students play themselves. This statement is in line with Kassim (2011), stating that physical education subjects cannot be implemented effectively due to time constraints, lack of equipment, inadequate facilities, unqualified teachers or less experienced teachers teaching physical education subjects.

\section{Conclusion}

Studies on the benefits and effectiveness of sport education in Malaysia are still lacking. Researchers should make effort to investigate whether the modules that were used in schools are really effective or not. The authors recommend that studies be conducted on identifying the features of the effective sports education program, the perception of the sports education program in order to enhance sports education in addition to improve the quality of future sports in the future.

\section{Acknowledgement}

This study was part of research funded by the Sultan Idris Education University under the Research Project Code 2017-0242-107-01 (GPU Khas Pendidikan).

\section{References}

Bailey, R. (2006). Physical education and sport in schools: A review of benefits and outcomes. Journal of School Health, 76(8), 397-401.

Bucher, C. A., \& Wuest, D. A. (1983). Foundation of physical education and sport. St. Louis, The CV Mosby Co., Toronto London, 16-36. 
INTERNATIONAL JOURNAL OF ACADEMIC RESEARCH IN BUSINESS AND SOCIAL SCIENCES

Vol. 8 , No. 12, Dec, 2018, E-ISSN:2 222 -6990 @ 2018 HRMARS

Bucher, C. A., \& Wuest, D. A. (2009). Physical Education, Exercise Science, and Sport: New York: Mc Graw Hill.

Colfer, G., Hamilton, K., Magill, R., \& Hamilton, B. (1986). Contemporav Physical Education. Dubuque, IA: Wm. C: Brown Publishers.

Darst, P. W., Pangrazi, R. P., Sariscsany, M. J., \& Brusseau, T. A. (2006). Dynamic physical education for secondary school students: Pearson/Benjamin Cummings.

Gabbard, C., LeBlanc, E., \& Lowy, S. (1994). Physical education for children: Building the foundation: Prentice-Hall.

Hardman, K., \& Marshall, J. (2009). Second world-wide survey of school physical education: ICSSPE.

Hattie, J., Marsh, H. W., Neill, J. T., \& Richards, G. E. (1997). Adventure education and Outward Bound: Out-of-class experiences that make a lasting difference. Review of Educational Research, 67(1), 43-87.

Hoe, W. E., Hua, K. P., \& Shaari, J. S. (2004). Needs analysis of physical education teachers in Malaysian primary schools.

Jani, J. (1994). Kualiti Masa Pembelajaran Akademik Dalam Pendidikan Jasmani: Kajian Kes Di Sekolah Menengah Daerah Hulu Langat, Selangor. Universiti Pertanian Malaysia.

Jenkins, J. M. (2004). Sport education in a PETE program. Journal of Physical Education, Recreation \& Dance, $75(5), 31-36$.

Jenny, J. H. (1961). Physical education, health education, and recreation: introduction to professional preparation for leadership: Macmillan.

Karim, Z., \& Nadzalan, A. M. (2017). The development of coaching knowledge among Malaysian accredited football coaches. International Journal of Academic Research in Progressive Education and Development, 6(4), 113-127.

Karim, Z. A., Ghafar, N. A. A., \& Nadzalan, A. M. (2018). The leadership style among football coaches leadership style among teachers in Hulu Langat district: The implications on National Football Development Program (NFDP) in Malaysia. International Journal of Academic Research in Business and Social Sciences, 8(3), 551-558.

Karim, Z. A., \& Nadzalan, A. M. (2017). Malaysia football coaches: Development characteristics. International Journal of Academic Research in Business and Social Sciences, 7(9), 305-312.

Knapp, C. G., \& Hagman, E. P. (1953). Teaching Methods for Physical Education: A Textbook for Secondary School Teachers: McGraw-Hill.

Kulinna, P. H. (2008). Models for curriculum and pedagogy in elementary school physical education. The Elementary School Journal, 108(3), 219-227.

Marshall, J., \& Hardman, K. (2000). The state and status of physical education in schools in international context. European Physical Education Review, 6(3), 203-229.

McCaughtry, N., Sofo, S., Rovegno, I., \& Curtner-Smith, M. (2004). Learning to teach sport education: Misunderstandings, pedagogical difficulties, and resistance. European Physical Education Review, 10(2), 135-155.

McKenzie, T. L., Nader, P. R., Strikmiller, P. K., Yang, M., Stone, E. J., Perry, C. L., . . Luepker, R. V. (1996). School physical education: effect of the Child and Adolescent Trial for Cardiovascular Health. Preventive medicine, 25(4), 423-431. 
McKenzie, T. L., \& Sallis, J. F. (1996). Physical activity, fitness, and health-related physical education. Student learning in physical education: Applying research to enhance instruction, 223-246.

Metzler, M. W., \& Tjeerdsma, B. L. (2000). Chapter 1: Teacher education program assessment and the GSU PETE assessment project. Journal of Teaching in Physical Education, 19(4), 395-401.

Pantanowitz, M., Lidor, R., Nemet, D., \& Eliakim, A. (2011). The Use of Homework Assignments in Physical Education among High School Students. ICHPER-SD Journal of Research, 6(1), 48-53.

Rahmat, A., Shahril, M., Salimin, N., Ahmad, M., Elumalai, G., Johan, R., \& Nadzalan, A. M. (2017). Cognitive domain achievement level among Reserve Officers Training Team (PALAPES). International Journal of Academic Research in Business and Social Sciences, 7(11), 198-203.

Rahmat, A., Shahril, M. I., Salimin, N., Ahmad, M. A. R., \& Nadzalan, A. M. (2017). The assessment of psychomotor domain among Reserve Officers Training Team (PALAPES). Journal of Fundamental and Applied Science, 9(6S), 1389-1397.

Rahmat, A., Shahril, M. I., Salimin, N., Ahmad, M. A. R., \& Nadzalan, A. M. (2018). The assessment of affective domain among PALAPES in UPSI. International Journal of Academic Research in Business and Social Sciences, 8(1), 293-299.

Sallis, J. F., \& McKenzie, T. L. (1991). Physical education's role in public health. Research Quarterly for Exercise and Sport, 62(2), 124-137.

Siedentop, D. (1994). Sport education: Quality PE through positive sport experiences: Human Kinetics Publishers.

Siedentop, D. (1998). What is sport education and how does it work? Journal of Physical Education, Recreation \& Dance, 69(4), 18-20.

Sinelnikov, O. A. (2009). Sport education for teachers: Professional development when introducing a novel curriculum model. European Physical Education Review, 15(1), 91-114.

Stran, M., \& Curtner-Smith, M. (2009). Influence of occupational socialization on two preservice teachers' interpretation and delivery of the sport education model. Journal of Teaching in Physical Education, 28(1), 38-53.

Stran, M., \& Curtner-Smith, M. D. (2009). Influence of two preservice teachers' value orientations on their interpretation and delivery of sport education. Sport, education and society, 14(3), 339-352.

Strikwerda-Brown, J., \& Taggart, A. (2001). No longer voiceless and exhausted: sport education and the primary generalist teacher. ACHPER Healthy Lifestyles Journal, 48(3/4), 14-17.

Wee, E.-H. (2013). Contemporary issues in the teaching of PE in Malaysia. Journal of Physical Activity, Sports, and Exercise, 1, 17-20.

Wuest, D. A., \& Bucher, C. A. (1991). Foundations of physical education and sport: Mosby Incorporated.

Wuest, D. A., \& Bucher, C. A. (1995). Foundations of Physical Education and Sport. St. Louis, Missouri: Mosby-Year Book: Inc. 